\title{
A GIS-BASED TSUNAMI EVACUATION MODEL CONSIDERING LAND COVER AND SPATIAL CONFIGURATION (CASE OF PURWOREJO REGENCY, INDONESIA)
}

\author{
F. F. Hakim ${ }^{a, b}$, W. T. de Vries ${ }^{\text {a }}$, F. Siegert ${ }^{\text {a }}$, J. A. Sjahbana ${ }^{c}$ \\ a Technische Universität München, Germany \\ ${ }^{b}$ Ministry of Public Works and Housing, Indonesia \\ ${ }^{c}$ Diponegoro University, Indonesia
}

\section{Article Info:}

Received: 20 November 2016 in revised form: 11 July 2017

Accepted: 26 August 2017

Available Online: 30 August 2017

\section{Keywords:}

Tsunami evacuation, land cover, spatial configuration, least cost path

Corresponding Author:

Febri Fahmi Hakim

Ministry of Public Works and

Housing, Jakarta, Indonesia

Email: febrifahmi@pu.go.id

\begin{abstract}
In Indonesia, several programs have dealt with tsunami mitigation, such as The German-Indonesian Tsunami Early Warning System (GITEWS) project (2005-2011). Despite the success of these projects, many coastal areas in Indonesia are still vulnerable to tsunamis, due to the variety of land cover and spatial configuration characteristics. One of such vulnerable areas includes Purworejo Regency. This paper evaluated the degree to which land cover and spatial configuration characteristics influence the tsunami evacuation process, and thus influence tsunami hazard mitigation. The evaluation drawn on data from a low to medium density populated coastal area of Purworejo Regency. The analysis relied on a quantitative approach, using a cross-sectional field survey, followed by a GIS-based analysis. This is complemented by a raster-based analysis to incorporate the land cover and spatial configuration aspects. The combined analysis derived which buildings could act as evacuation buildings in case of a tsunami. The associated tsunami evacuation routes were calculated using a Least Cost Path (LCP) analysis method. The results suggested that several public facility buildings are likely to be used as tsunami evacuation buildings. Yet, even though the overall capacity of these buildings is adequate to accommodate the estimated number of evacuees in a larger area, the specific demand at certain locations in the study area is much higher than these localities can handle. This disproportionate spatial variation in required capacity needs further attention. Moreover, the survey responses indicated that the majority of the respondents was not well informed regarding the tsunami evacuation procedures.
\end{abstract}

How to cite (APA 6th Style):

Hakim, F. F, et. al. (2017). A Gis-Based Tsunami Evacuation Model Considering Land Cover and Spatial Configuration (Case of Purworejo Regency, Indonesia). Geoplanning: Journal of Geomatics and Planning, 4(2), 143-156. doi:10.14710/geoplanning.4.3.143-156

\section{INTRODUCTION}

A tsunami is a particularly disastrous natural hazard. The threat of this natural disaster remains hidden until it is triggered by an earthquake on the seabed. The degree of devastation of tsunamis has been shown by the Aceh Tsunami on 26th December 2004, which shattered $413 \mathrm{~km}^{2}$ in the Aceh Province's coastal area alone (Samek, Skole, \& Chomentowski, 2004), whilst also affecting many other parts of coastal areas around the Indian Ocean.

The Aceh tsunami disaster initiated several programs and activities to support tsunami mitigation in Indonesia. One of the most noticeable examples concerned GITEWS, the German-Indonesian Tsunami Early Warning System project (2005-2011), later known as InaTEWS (Indonesia Tsunami Early Warning System). Despite the proclaimed success of the project (Münch, Rudloff, \& Lauterjung, 2011), its implementation is not considered completed (Agency for Meteorology Climatology and Geophysic, 2010). At local level, GITEWS has enabled tsunami hazard zone mapping through detailed tsunami inundation modelling in three different locations: Kuta (Bali), Padang (West-Sumatra), and Cilacap (Central Java) (Gayer et al., 2010). Meanwhile, many other areas were assessed using empirical methods to classify coastal area hazard classes 
to be used as a basis for developing a tsunami hazard risk map (Sturnz et al., 2011). As of 2009 the Purworejo regency became part of the GITEWS project area, which resulted in a Tsunami Hazard Risk Maps for Purworejo as well.

However, a closer look at the tsunami hazard risk map and the tsunami evacuation map produced for Purworejo Regency revealed that the level of detail is limited. Moreover, detailed studies on tsunami hazard risk in Indonesia mostly focus on areas which include either critical infrastructures or highly developed urban areas (Budiarjo, 2006; Dewi, 2010; Fakhrurrazi \& Nes, 2012; Gayer et al., 2010; Sturnz et al., 2011). As a consequence, regular settlement areas often receive less attention in these risk mapping endeavours, although most coastal areas of West Sumatera and the southern part of Java are particularly prone to tsunamis. Therefore, many villages in tsunami-prone coastal areas in Indonesia with different land cover and spatial configuration characteristics are still vulnerable, including the Purworejo Regency.

The suggestion that land cover and spatial configuration characteristics influencing tsunami evacuation process is not a novel idea on its own. Gayer et al. (2010) connected land cover of densely populated coastal areas to tsunami inundation extents. Wood (2009) related land cover with community assets, implying that more developed urban areas would have higher and more significant capacity for evacuees. Wood \& Schmidtlein (2012) analyzed the tsunami evacuation of the pedestrian on the different land cover by incorporating the speed conservation value of each land cover classes. Fakhrurrazi \& Nes (2012) examined the influence of the spatial configuration in a tsunami evacuation process regarding Aceh Tsunami in 2004, from an architectural perspective. Both studies suggested that a different land cover and spatial configuration characteristics of the tsunami-prone coastal areas could influence the tsunami evacuation process to the safe zone.

Nevertheless, there are limited studies which examine the land cover aspect and directly relate it to the spatial configuration issue on a tsunami evacuation context of the low to medium density populated tsunami-prone coastal area. Previous studies examined either impact of the land cover or the impact of spatial configuration, as two independent aspects. Gayer et al. (2010) focused on the use of a detailed roughness map to develop tsunami inundation model for three pilot areas (i.e. Padang, Cilacap, and Kuta). Kaiser et al. (2011) studied the influence of land cover roughness to the tsunami inundation which shows the influence of dense vegetation and the built environment on tsunami flow velocities. Romer et al. (2012) investigated the use of remote sensing techniques and data for determining the ground elevation and land cover information for tsunami hazard assessment. Kaiser et al. (2013) examined the result of tsunami wave flows on land cover and the corresponding ecosystem. Meanwhile, among the limited study, Lonergan (2011) focused on the spatial configuration aspect by employing visibility analysis considering topographical elevation and land cover for an optimum placement of tsunami evacuation signs.

The aim of this paper was to evaluate the degree to which land cover and spatial configuration together influence the options for the tsunami evacuation process, and the decisions in relation to tsunami hazard mitigation in a low to medium density populated coastal area in Purworejo Regency. The paper has the following sequence: the subsequent section introduces the profile of the study area, followed by the research method. The next section discusses the GIS-based tsunami evacuation model considering land cover and spatial configuration aspects for Purworejo Regency, which comprises the identification of Potential Tsunami Evacuation Buildings (PTEB) and Potential Tsunami Evacuation Routes (PTER) in the study area. The last section provides general conclusions and a number of practical recommendations.

\section{DATA AND METHODS}

\subsection{Study Area}

The study area is located in the Southern part of Java Island, facing the Java Trench in the Indian Ocean. The study area consisted of 6 (six) villages in the coastal regions of Purworejo Regency, namely: Harjobinangun (Grabag sub-district), Keburuhan, Awu-Awu, Depokrejo, Kumpulsari, and Kaliwungu Kidul (Ngombol sub-district). The study area was selected for its geographical features as compared to other coastal areas along the coastline of Purworejo Regency, and the historical occurrences of tsunamis in the region. Figure 1 illustrates the study area. 

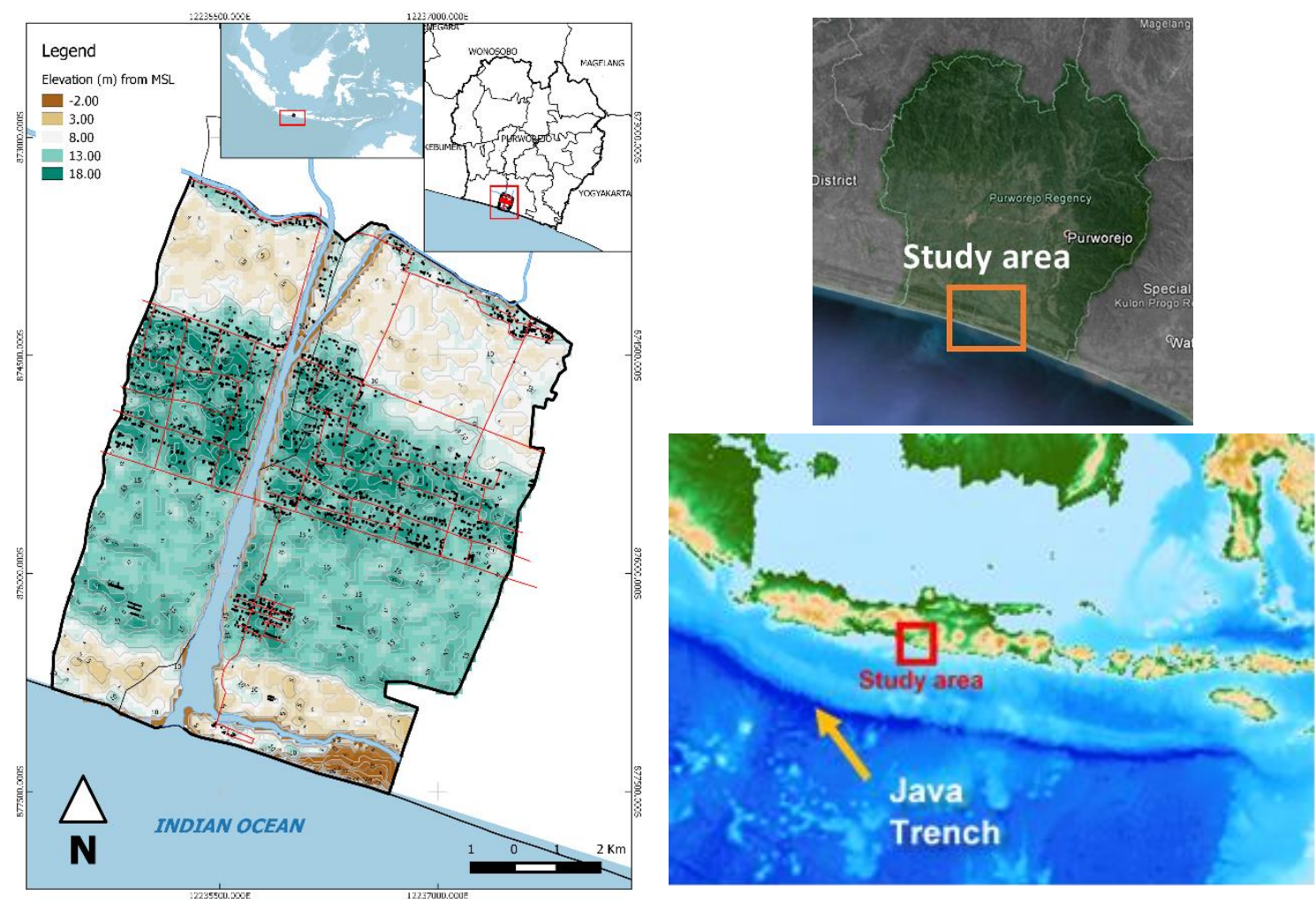

Figure 1. The study area (base map source from BIG and SRTM 1-arc second (left). Bathymetry data ETOPO2 is from GEBCO (bottom-right). Google Earth imagery (top-right))

The coast of the study area is plain beach, with a slight elevation from mean sea level (MSL). The beach is the lowest part which has an elevation of about 1-2 meters above MSL. Around 500 meters away from the coastline, there is a long sand dune formation parallel to the shore. But since 2000's, the villagers started to convert many parts of the beach as shrimp farms, nowadays one can find shrimp farms everywhere near the beach, both in the East and Western part of the river. Mangrove trees exist in some spots along the beach on the east of Jali River, but these are limited in number. On the Western part of Jali River, there is the formation of tall trees parallel to the coastline with a strip width of around 50 meters.

The land cover and land use in the study area is dominated by the agriculture and residential area (Pemerintah Kabupaten Purworejo, 2011). Close to the coastline, the dominating land use is shrimp farms, and rain-fed agriculture. Near the rain-fed agricultural area and shrimp farms in the Eastern part of the river, the land cover is characterized by the presence of a built environment cluster, which is part of Keburuhan Village. Since the study area is not a downtown area, the spatial configuration of the study area is not as dense as the nearby urban area, Kutoarjo, in the North direction. The distribution of buildings in the study area mostly follows the road networks; either the primary road network passes the area or the road network in the village. In between buildings there still vast areas of greeneries with big trees.

\subsection{Methods and Dataset}

This study focused on the use of mostly free and open source software to support the analysis stage, to encourage the local disaster management stakeholders with a tight operational budget to use the methods described in this study. In the tsunami evacuation modeling stage, five data types were used: numerical data, raster data, vector data, qualitative data (including photos and non-numerical information collected during the field visits) and interview responses. The numerical data consisted of demographic data of the study area; the time series data of the tsunami wave propagation (result of the tsunami propagation simulation), and the data resulted from the semi-structured interviews using a questionnaire. The interviews were conducted to support the building inventory process, to examine understanding of respondents of spatial configuration (i.e. by giving questions which contain a pair of satellite images with five marks to be selected according to its corresponding environment in the form of perspective sketches), 
and to assess their vehicle ownership and evacuation transport preferences. The population data was collected in 10 Participatory GIS (P-GIS) mapping sessions with 13 key respondents who were village officers in the study area. The time series data of the tsunami wave propagation were obtained from the tsunami simulation in Hakim (2016). Meanwhile, the tsunami source model used in the tsunami simulation stage was derived and adapted from Kongko and Hidayat (2014).

The raster data consisted of LANDSAT 7 ETM+ SLC-Off, which is used in the land cover analysis stage; the gridded bathymetry data (30-arc second) which was downloaded from GEBCO website (http://www.gebco.net); and, the SRTM (1-arc second) dataset which was downloaded from (http://eros.usgs.gov). The latter datasets were used in the tsunami propagation, run-up, and inundation simulation stage. Meanwhile, the vector data were obtained from the Indonesian Geospatial Information Agency and the Local Development Agency of Purworejo Regency.

The tsunami simulations stage was carried out in easyWave and ANUGA using the method described in Babeyko (2012) and Roberts et al. (2015). The LANDSAT imageries merged following the gap filling method described in USGS (2004). Then, the land cover classification (supervised) was carried out in Monteverdi before the tsunami run-up and inundation simulation conducted in ANUGA, to determine the friction values applied for each land cover class in the model.

The tsunami evacuation modeling was carried out in QGIS 2.82 Wien. First, the Potential Tsunami Evacuation Buildings (PTEB) were identified, by overlaying the tsunami prone area map resulted from the tsunami simulation stage. The service area of each PTEB was also examined by incorporating the Cell-Cross Time (CCT) concept (Juliao, 1999) by considering the tsunami evacuation time constraint resulted from the tsunami simulation. After this process, the Potential Tsunami Evacuation Routes (PTER) was identified using the Least Cost Path (LCP) method. The inverse Speed Conservation Value (SCV) (Wood \& Schmidtlein, 2012) and the inverse Sky View Factor (SVF) (Grimmond et al., 2001) were used as a proxy for developing a cost raster layer. The spatial configuration analysis was carried out by calculating two-dimensional cumulative isovist of each potential tsunami evacuation route. The least cost paths resulted were simplified to one evacuation path for each group of paths to certain potential tsunami evacuation building, which represents the longest and the most used evacuation paths used by the evacuees. The line was then converted into points in a regular interval $(100 \mathrm{~m})$ as a base for generating the individual isovist for each point. The resulted isovist were merged to calculate the cumulative isovist for each potential tsunami evacuation route.

\section{RESULT AND DISCUSSION}

\subsection{A GIS-based Tsunami Evacuation Model for Purworejo Regency}

There are several available tsunami evacuation models which could be applied in the study area. These models are often grouped into several types, such as traffic model, evacuation behaviour model, and timeline/critical path management model. In this study, we considered two approaches for GIS-based tsunami evacuation modeling: a vector-based approach (Budiarjo, 2006; Dewi, 2010), and a raster-based approach (Mück, 2008; Wood \& Schmidtlein, 2012).

The raster-based model was selected as the basis for tsunami evacuation modeling in this study, to be able to accommodate the land cover and the spatial configuration consideration into the model. Since the slope is not considered in this model, the accumulated cost (isotropic) geo-algorithm was used to represent the same weight in all directions. The CCT concept was combined with the SCV concept in order to derive the service area map of each PTEB in the study area. The LCP method was the used to identify the PTER for the tsunami evacuation. In addition, the spatial configuration analysis was done by calculating the cumulative isovist of each PTER to assess the performance of each PTER regarding the visibility in a tsunami evacuation context.

\subsection{The Incorporation of Land Cover and Spatial Configuration in the Tsunami Evacuation Model}

The land cover factor was incorporated into the tsunami evacuation model by applying the CCT concept combined with the inverse SCV concept. The spatial configuration aspects are integrated into the 
model by using the inverse SVF concept. The CCT map derived from the evacuee walking speed standard described in FEMA (2008) (see Table 1). This walking speed standard was then used to calculate what Juliao (1999) calls the "cell crossing time" (CCT). The cell crossing time (CCT) is the time needed to pass through one raster cell in a GIS environment, which represents the time required to travel a particular distance in a real environment. In a GIS environment, this particular range is the same as the cell size (e.g. Raster layer in QGIS with a cell size of 1 unit on the map which is projected in UTM projection, will have 1-meter distance for each cell). By utilizing the CCT in combination with the SCV concept, we could develop a cost surface raster layer containing value regarding the time spent to cross one raster pixel in different land cover classes. Only then we could generate the accumulated cost surface layer to analyze the catchment/service area of each PTEB, based on the total time needed to go to the PTEB from any location in the tsunami prone area.

Table 1. The evacuee walking speed standard (FEMA, 2008)

\begin{tabular}{cccc}
\hline Warning time & Walking speed & Travel distance & TEB spacing \\
\hline 2 hours & $2 \mathrm{mph}(0.89 \mathrm{~m} / \mathrm{s})$ & 4 miles $(6.4 \mathrm{~km})$ & 8 miles $(12.8 \mathrm{~km})$ \\
\hline 30 minutes & $2 \mathrm{mph}(0.89 \mathrm{~m} / \mathrm{s})$ & 1 mile $(1.6 \mathrm{~km})$ & 2 miles $(3.2 \mathrm{~km})$ \\
\hline 15 minutes & $2 \mathrm{mph}(0.89 \mathrm{~m} / \mathrm{s})$ & $1 / 2$ mile $(0.8 \mathrm{~km})$ & 1 miles $(1.6 \mathrm{~km})$ \\
\hline
\end{tabular}

The least cost path analysis focuses on land cover constraints with two costs aspects: "speed conservation value (SCV)", and "sky view factor (SVF)". Speed conservation value represents the amount of speed conserved during a movement in a different land cover classes (Wood \& Schmidtlein, 2012). The higher the SCV, the higher the evacuee movement speeds on that particular land cover class. Meanwhile, the sky view factor represents the amount of the sky opening above the observer in different surrounding environments (Grimmond et al., 2001), which could also imply the amount of natural light (e.g. daylight from the sun, or natural light during the night from the moon) which penetrates the different land cover classes. The higher the SVF in one location, the greater the amount of natural light penetrates this place. Both factors share the same numeric scale, between 0 and 1 , which is suitable to be used in the least cost path analysis. However, in this research, the value will be inverted to represent the inverse SCV and inverse SVF value, to be able to compute the least-cost path correctly. It means that the higher the inverse SCV and the inverse SVF value in certain pixels, the higher the cost to pass through those pixels.

The SCV value used in this research is based on the SCV value developed in Soule \& Goldman (1972), and further used by Wood and Schmidtlein (2012), as an interpretation of National Land Cover Database (NLCD) into a set of coefficients of energy cost prediction. The NLCD itself is a land cover map product of the US Government developed by the Multi-Resolution Land Cover Characteristics (MLRC) Consortium (USGS, 2015). In this study, we used the inverse SCV value to represent the movement cost/impedance of different land cover classes.

Similarly, we also used the SVF value indirectly, by changing the SVF value to reflect the opposite condition using the similar method used for SCV. The SVF value utilized in this analysis is based on the work of Grimmond et al. (2001), who conducted an observation of the SVF in a small city Bloomington in the United States. The inverse SCV and inverse SVF values used in this analysis, and the corresponding SCV and SVF value of the original research, are described in Table 2 and Table 3.

\subsection{The PTEB and the Corresponding PTER in the Study Area}

The nominee of the PTEB is selected from the public facility and social facility buildings in the study area. These structures are chosen since public service building usually has several advantage compared to the private housing. First, the public facility buildings usually have wider floor area with an open plan space which is suitable to be used as temporary evacuation space. Furthermore, public service buildings such as school often equipped with a large yard where the temporary shelter can be build. This building is also often equipped with the required service areas (e.g. clean water, sanitation, kitchen, and so on).

Twenty public facility or social facility buildings are nominated as the PTEB. However, after these building's location (which is represented by point layer in QGIS) overlaid with the Tsunami Prone Area Map, 
there are only nine buildings located in the safe areas. Therefore, only these nine buildings are potentially to be functioned as tsunami evacuation buildings. Figure 2 shows the selected PTEB in the study area.

Meanwhile, the service area for each PTEB was calculated using the 30 minutes' tsunami evacuation time constraints resulted from the tsunami simulation in easyWave (Hakim, 2016). Since the service area map of each PTEB derived from the CCT and SCV alone is overlapping each other, the Voronoi polygon is used to divide the service area within the 30 minutes' evacuation timeframe. The Voronoi diagram represents the area where all points within this field are closer to the point which is predefined as its center, compared to other center points (Menke et al., 2015). That is why the Voronoi diagram is often used to define the service area of particular center points such as a public facility.

Table 2. The inverse SCV value used in the GIS analysis

(Soule \& Goldman, 1972; Wood \& Schmidtlein, 2012)

\begin{tabular}{|c|c|c|c|c|}
\hline $\begin{array}{l}\text { NLCD categories in Wood \& } \\
\text { Schmidtlein (2012) }\end{array}$ & $\begin{array}{l}\text { Soule and } \\
\text { Goldman's } \\
\text { surface } \\
\text { categories }\end{array}$ & $\begin{array}{l}\text { SCV value in } \\
\text { Wood \& } \\
\text { Schmidtlein } \\
(2012)\end{array}$ & $\begin{array}{l}\text { Land cover category in this } \\
\text { research }\end{array}$ & $\begin{array}{l}\text { Inverse } \\
\text { SCV }\end{array}$ \\
\hline Roads & Blacktop & 1 & Road network & 0 \\
\hline Open water & None & 0 & River & 1 \\
\hline Developed, open space & Dirt road & 0.9091 & - & - \\
\hline Developed, low intensity & Dirt road & 0.9091 & - & - \\
\hline Developed, medium intensity & Dirt road & 0.9091 & Settlement, medium density & 0.0909 \\
\hline Developed, high intensity & Dirt road & 0.9091 & Settlement, high density & 0.0909 \\
\hline Barren land & Hard sand & 0.5556 & - & - \\
\hline Deciduous forest & Light brush & 0.8333 & - & - \\
\hline Evergreen forest & Light brush & 0.8333 & Vegetation, medium density & 0.1667 \\
\hline Mixed forest & Light brush & 0.8333 & - & - \\
\hline Shrub/scrub & Heavy brush & 0.6667 & Vegetation, high density & 0.3333 \\
\hline Grassland/herbaceous & Light brush & 0.8333 & Beach & 0.1667 \\
\hline Pasture/hay & Light brush & 0.8333 & - & - \\
\hline Cultivated crops & Light brush & 0.8333 & Agriculture (irrigated/rain fed) & 0.1667 \\
\hline Woody Wetlands & Swampy Bog & 0.5556 & - & \\
\hline Emergent Herbaceous wetland & Swampy Bog & 0.5556 & - & \\
\hline
\end{tabular}

Table 3. The inverse SVF used in this study (adapted from Grimmond et al., 2001)

\begin{tabular}{|c|c|c|c|}
\hline $\begin{array}{l}\text { Land use categories in Grimmond } \\
\text { et al. (2001) }\end{array}$ & $\begin{array}{l}\text { Mean SVF value in } \\
\text { Grimmond et al. (2001) }\end{array}$ & Land cover types in this research & Inverse SVF \\
\hline- & None & River & $\begin{array}{l}\text { Assumed to } \\
\text { be } 1.0\end{array}$ \\
\hline Downtown & 0.83 & $\begin{array}{l}\text { Settlement, high density; Vegetation } \\
\text { (medium/high density }\end{array}$ & 0.17 \\
\hline Single-family residential & 0.85 & Settlement, medium density & 0.15 \\
\hline Estate residential & 0.87 & - & - \\
\hline Institutional & 0.88 & - & - \\
\hline Multi-family residential & 0.91 & - & - \\
\hline Parks/open space & 0.92 & Agriculture (irrigated/rain fed); Cropland & 0.08 \\
\hline Manufactured housing & 0.93 & - & - \\
\hline Vacant & 0.93 & Beach & 0.07 \\
\hline Commercial & 0.94 & - & - \\
\hline Industrial & 0.97 & - & - \\
\hline
\end{tabular}




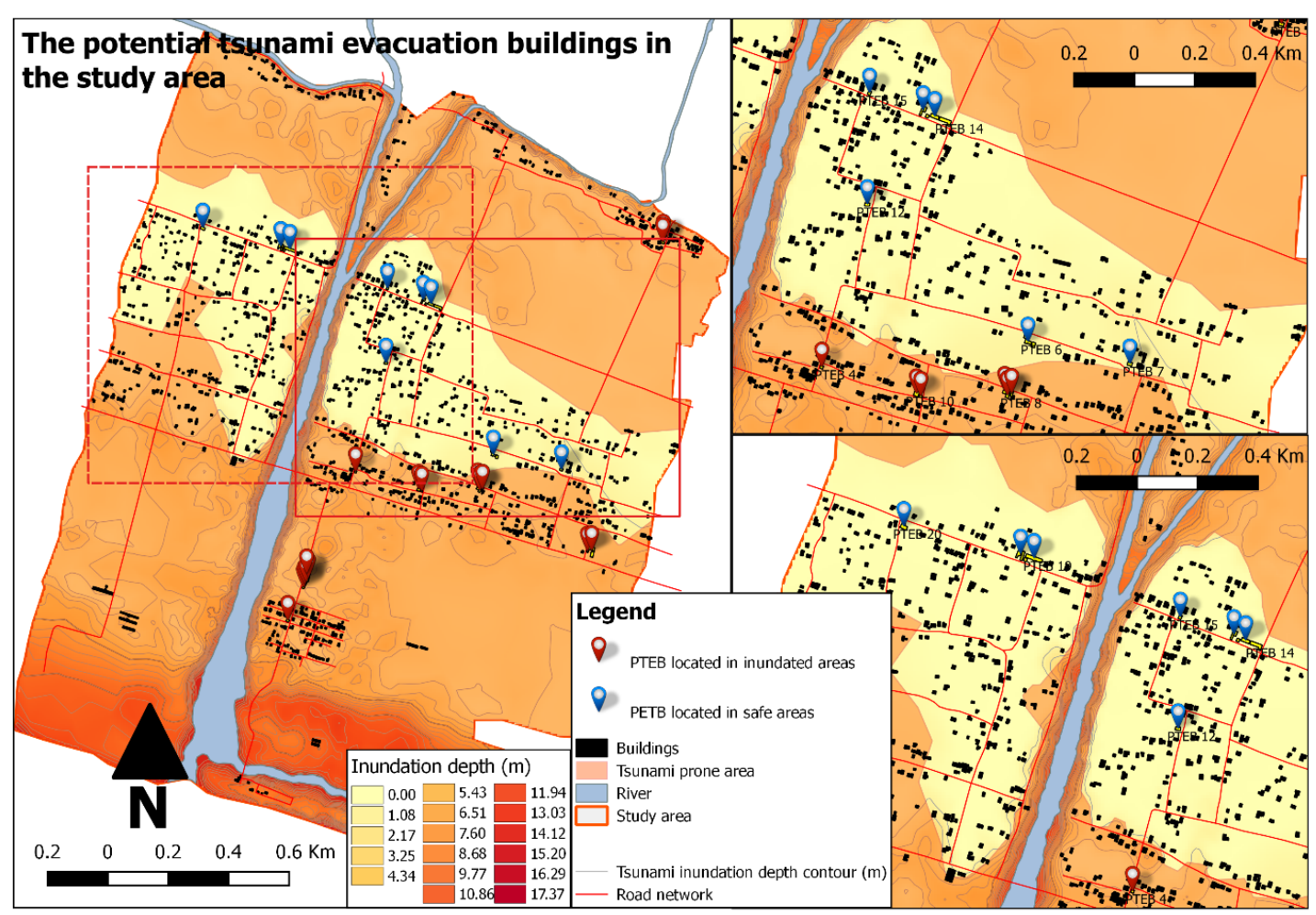

Figure 2. The potential tsunami evacuation buildings (PTEB) in the study area (analysis, 2016)

The calculation results of the capacity of each PTEB compared to the potential evacuees from each service area shows that the capacity of six PTEBs could meet the demand while three others are over capacity. Meanwhile, for the night time scenario, four PTEBs are adequate in accommodating the evacuees, but five others are over capacity. However, the calculation of the total capacity of the PTEBs and the total evacuees shows that the capacity of the PTEBs is adequate to shelter the evacuees. The result indicates a disproportion of tsunami evacuation capacity in the study area, which needs further attention. Therefore, some PTEBs are needed to be improved to be able to meet the number of the potential evacuees within its service area. The calculation results are presented in Table 4.

Table 4. The number of evacuees served by each PTEB (analysis, 2016)

\begin{tabular}{|c|c|c|c|c|c|c|c|}
\hline \multirow[t]{2}{*}{ PTEB } & \multirow[t]{2}{*}{$\begin{array}{l}\text { Adjusted PTEB } \\
\text { service area } \\
(\mathrm{Sq} \cdot \mathrm{km})\end{array}$} & \multicolumn{2}{|c|}{$\begin{array}{l}\text { Potential evacuees } \\
\text { within service area }\end{array}$} & \multicolumn{2}{|c|}{$\begin{array}{l}\text { The capacity of the } \\
\text { PTEB (after } \\
\text { adjustment) }\end{array}$} & \multicolumn{2}{|c|}{$\begin{array}{c}\text { The evacuees that are not } \\
\text { accommodated }\end{array}$} \\
\hline & & Day & Night & Day & Night & Day & Night \\
\hline PTEB 6 & 1.54 & 771 & 910 & 357 & 357 & 414 & 553 \\
\hline PTEB 7 & 1.53 & 247 & 324 & 108 & 88 & 139 & 236 \\
\hline PTEB 12 & 1.3 & 513 & 657 & 142 & 122 & 371 & 535 \\
\hline PTEB 13 & 0.22 & 19 & 57 & 294 & 294 & $(-275)^{*}$ & $(-237) *$ \\
\hline PTEB 14 & 0.86 & 111 & 272 & 726 & 856 & $(-615)^{*}$ & $(-584)^{*}$ \\
\hline PTEB 15 & 0.39 & 32 & 90 & 53 & 68 & $(-21)^{*}$ & 22 \\
\hline PTEB 18 & 0.38 & 40 & 95 & 361 & 361 & $(-321)^{*}$ & $(-266) *$ \\
\hline PTEB 19 & 0.43 & 99 & 161 & 756 & 886 & $(-657) *$ & $(-725)^{*}$ \\
\hline PTEB 20 & 1.23 & 143 & 385 & 307 & 287 & $(-164)^{*}$ & 98 \\
\hline TOT A L & 7.88 & 2007 & 2951 & 3104 & 3319 & 924 & 1444 \\
\hline
\end{tabular}

\section{Notes:}

* Indicates a surplus in capacity. The surplus of PTEB's capacity for the day time scenario is 2053 while the night time scenario is 1812. Compared to the unaccommodated evacuees, the surplus is 1129 (daytime scenario) and 368 (night time scenario). However, this result suggests the disproportion of PTEB capacity versus the demand. 
The corresponding PTER was then identified using the LCP method as previously described. The additional spatial configuration analysis was carried out by applying the view shed analysis on each PTER, which is resulted in the LCP analysis. After this process, the performance of each PTER was then examined regarding the spatial configuration aspects, from the architectural perspectives.

The least cost path analysis relied on the shortest path algorithm developed by Dijkstra (1959), finding the shortest path between a source point and a destination point (Schmidtlein \& Wood, 2015). In a GIS environment, Dijkstra's algorithm could be carried out on both vector and raster layer. In the raster-based analysis, like in LCP analysis, the calculation is conducted for each raster cell, from the source raster cell to the destination cell by continuously moving around the Moore neighborhood. A Moore neighborhood is the area of eight raster cells, which are the nearest neighbor to the center cell (Schiff, 2011).

In the LCP analysis, the algorithm iteratively evaluates the value of the cells in a Moore neighborhood and selects the cells which have the lowest cost in that cells neighborhood, in the predefined accumulated costs raster layer. The LCP analysis computes the least cost distance between the destination points and the source points (Figure 3). By incorporating the land cover and spatial configuration aspects into the cost surface layer, we can model the influence of land cover and spatial configuration to the selection of the potentially the most preferable path to travel through during a tsunami evacuation. The hexagonal tessellation is adapted from Budiarjo (2006) and Dewi (2010) to simplify the evacuee source points in the model.

The analysis result shows there are 221 least cost paths resulted from the source points (hexagon centroids) to the destination PTEBs. The result is then exported into a spreadsheet file and analyzed. In a spreadsheet program, these paths are categorized into two different categories regarding the travel time, namely: "Safe" path, and "Not safe" path. The Safe Path category represents the paths which have less than 30 minutes travel time, based on the standard evacuee speed described in FEMA (2008).

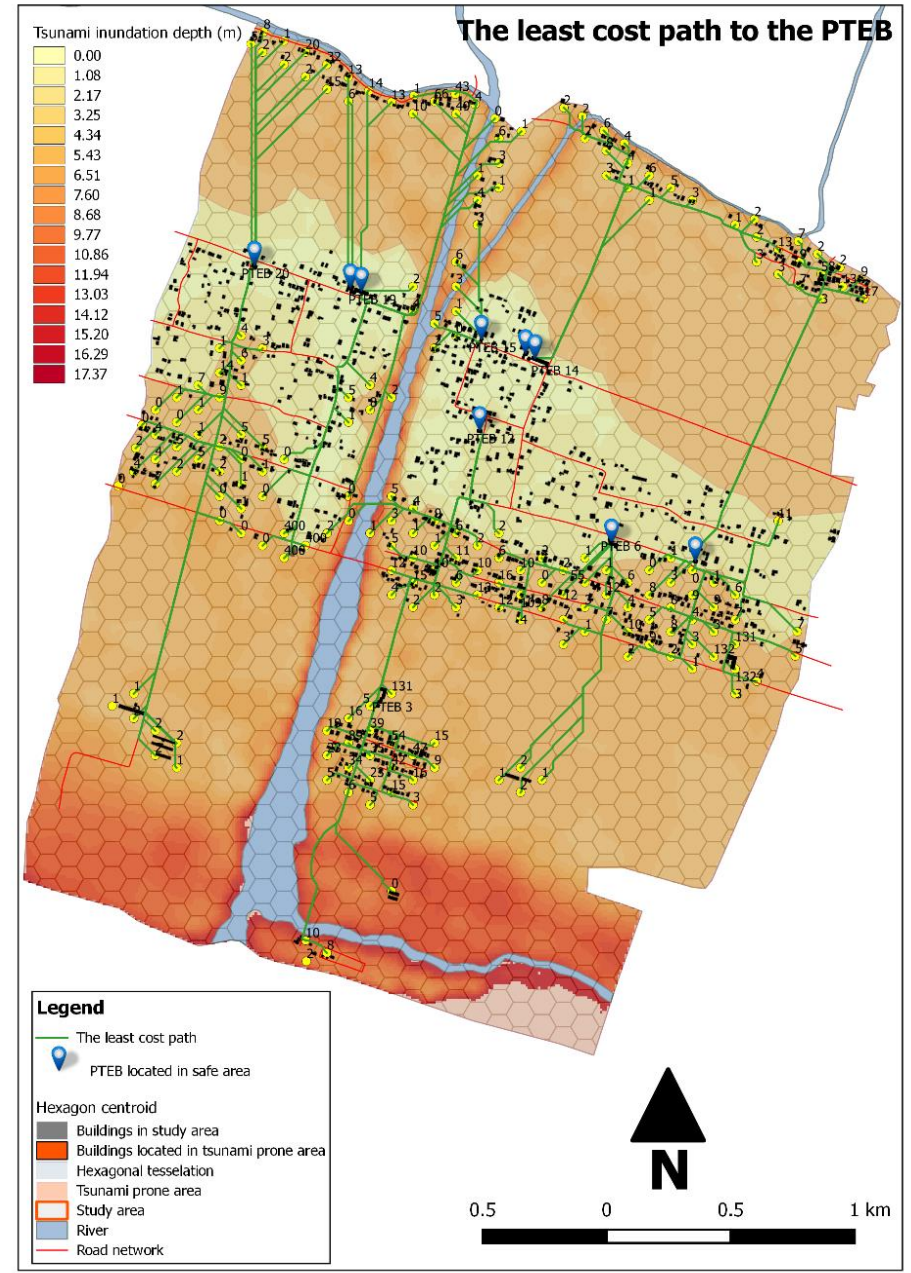

Figure 3. The least cost path between the evacuee source points and the PTEB (analysis, 2016) 


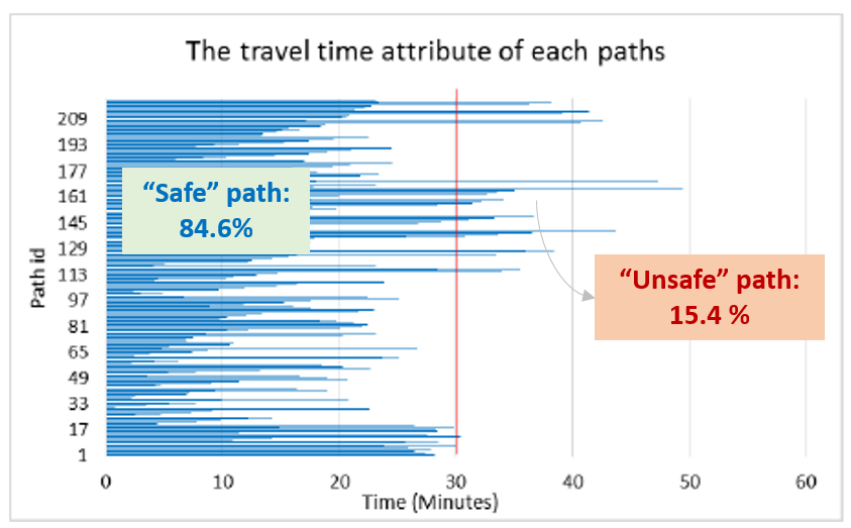

Figure 4. The travel time attribute of each least cost path (analysis, 2016)

The result shows 28 paths categorized as "Not safe", and 193 paths categorized as "Safe" (Figure 4). However, these 28 paths share a common line and direction to the PTEBs. The difference is that the former are longer to travel through by the evacuees than the latter. This difference is usually due to some building blocks which are located closer to the coastline and has a greater distance to the PTEB. The road space utilization within the 30 minutes evacuation timeframe is presented in Figure 5.

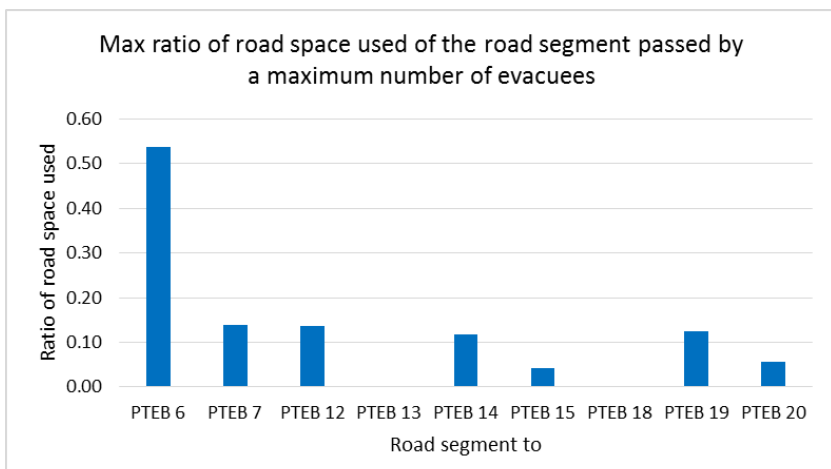

Figure 5. Maximum ratio of road space used at the road segment passed by the maximum number of evacuees (analysis, 2016)

The view shed analysis is carried out to examine the performance of each PTER. This process was done by analyzing the cumulative binary view shed or isovist to model how much the observer (i.e. the evacuee) would see the surrounding environment when he/she moves along the particular PTER. The model is the simplified version of the reality, considering only the position of the evacuee on some points with 100 meters spacing along the path. By knowing the cumulative isovist of each PTER, we could examine the location along the PTER which potentially raise confusion among the evacuees during the tsunami evacuation process, due to the spatial configuration aspect.

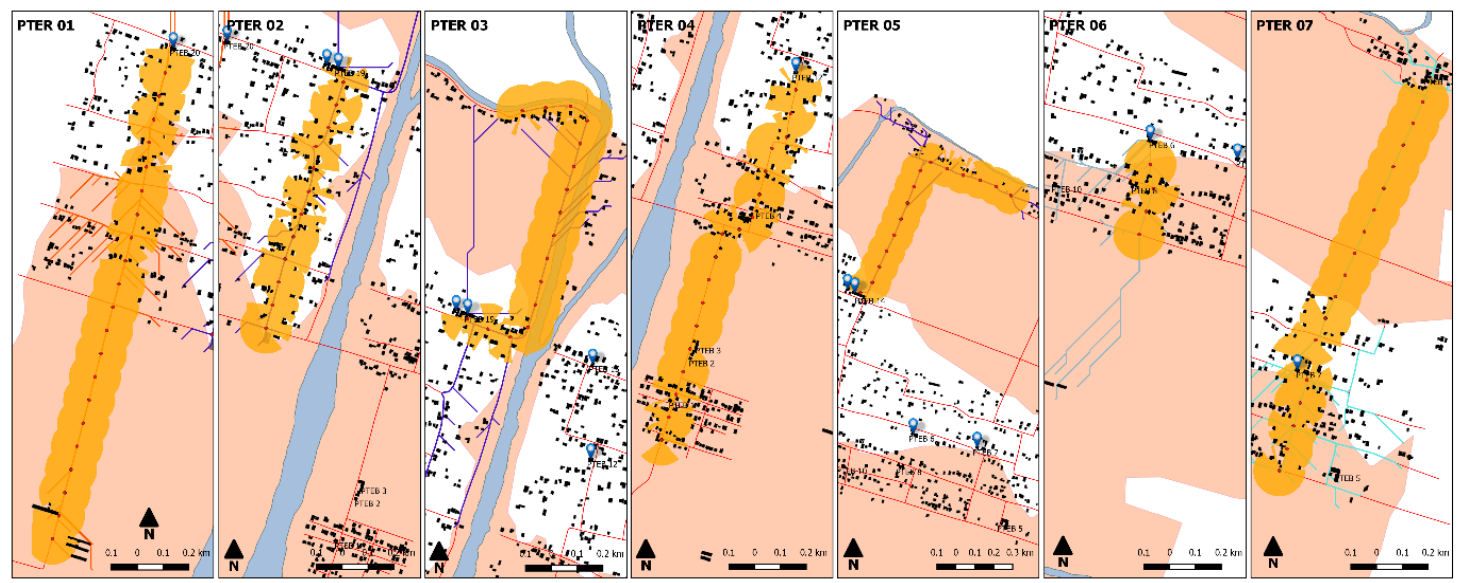

Figure 6. The visibility profile (cumulative binary viewshed) of each PTER (analysis, 2016) 
Figure 6 shows the influence of the spatial configuration in the surroundings of each PTER. The displayed routes represent a ratio value of cumulative PTER isovist to full cumulative isovist of the same path but without obstruction of more than 0.8 . This means that the evacuees would have quite a good visibility when they proceed for the tsunami evacuation through these PTER (see Table 5). However, these are the calculation of the cumulative isovist and not the individual isovist. Although the overall visibility of the PTER can thus be considered quite well, there is also a possibility that in some locations or intersections, the visibility drops with almost 50 percent. This number implies that in assessing the PTER, a disaster manager should also determine the presence of such spatial configuration along the PTER, in order to ensure the appropriate intervention is done in this particular area.

Table 5. The comparison of PTER isovist with the full cumulative isovist on the same path but without obstruction (analysis, 2016)

\begin{tabular}{|ccccc|}
\hline PTER & Length of path $(\mathrm{m})$ & $\begin{array}{c}\text { Isovist area (cumulative) } \\
\text { (PTER isovist) } \\
\left(\mathrm{m}^{2}\right)\end{array}$ & $\begin{array}{c}\text { Cumulative isovist } \\
\text { area of the same } \\
\text { length without } \\
\text { obstruction }\end{array}$ & $\begin{array}{c}\text { Ratio of PTER isovist } \\
\text { to cumulative isovist } \\
\text { of the same length } \\
\text { without obstruction }\end{array}$ \\
\hline PTER 1 & 2200 & 375973.796 & 413002.715 & 0.91 \\
\hline PTER 2 & 1180 & 189328.2131 & 229051.0061 & 0.83 \\
\hline PTER 3 & 1500 & 266260.4612 & 298929.1825 & 0.89 \\
\hline PTER 4 & 1700 & 279790.8475 & 327655.906 & 0.85 \\
\hline PTER 5 & 1400 & 258468.1716 & 277937.5665 & 0.93 \\
\hline PTER 6 & 300 & 77606.5676 & 86455.2637 & 0.90 \\
\hline PTER 7 & 1600 & 319254.0109 & 339612.4514 & 0.94 \\
\hline
\end{tabular}

\subsection{Field Validation}

The field survey enabled the collection of demographic data, which derived the building inventory as well. Alongside this information the responses revealed is the ability of people in how each interprets and connects the spatial information contained in a map or in a satellite images, and how they relate it to the corresponding actual environment (the example of images used in the question regarding spatial configuration is illustrated in Figure 7). This crucial insight shows how people understand maps in the context of a tsunami evacuation process, and this helps how disaster managers can deal with this aspect.

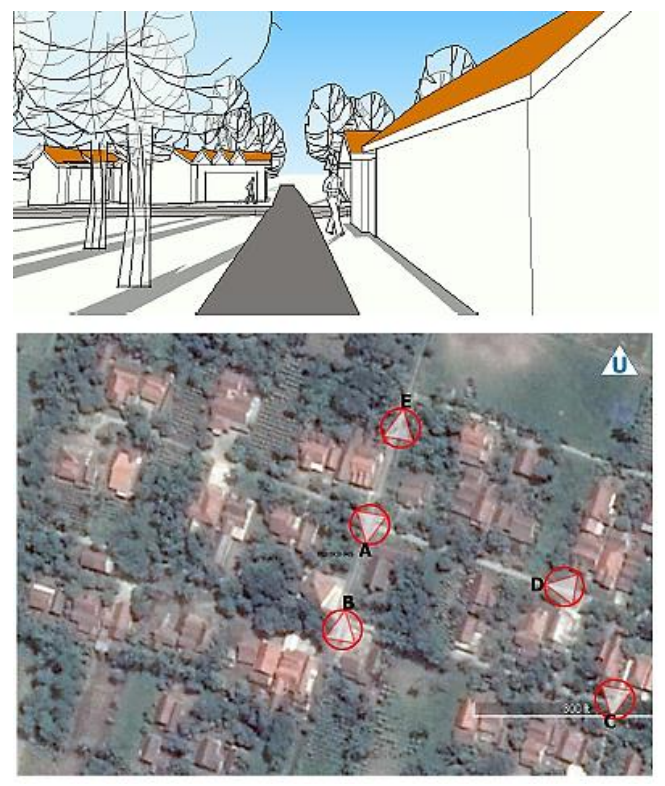

Figure 7. The example of pair image used in the question regarding spatial configuration aspect (analysis, 2016) 
The field survey yielded a variety of insights in spatial understanding and associated choices in behavior. Most of the respondents had a basic degree of spatial awareness. However, around 70 percent of the respondents correctly answered only three out of ten questions related to this aspect, while only 2.1 percent respondents can answer $80 \%$ of these questions correctly. These results suggest that spatial awareness is clearly different from working consistently with maps and deriving decisions on this.

A further look into the response time of the interviewees to the spatial configuration questions (Figure 8) shows an interesting trend. After answering several questions, the trend shows the decreasing average response time in answering the questions in spatial configuration aspect. However, since the number of correct answers is very low compared to the wrong answer in this type of question, there is a possibility that the small response time does not result from the better respondent's understanding of the questions.

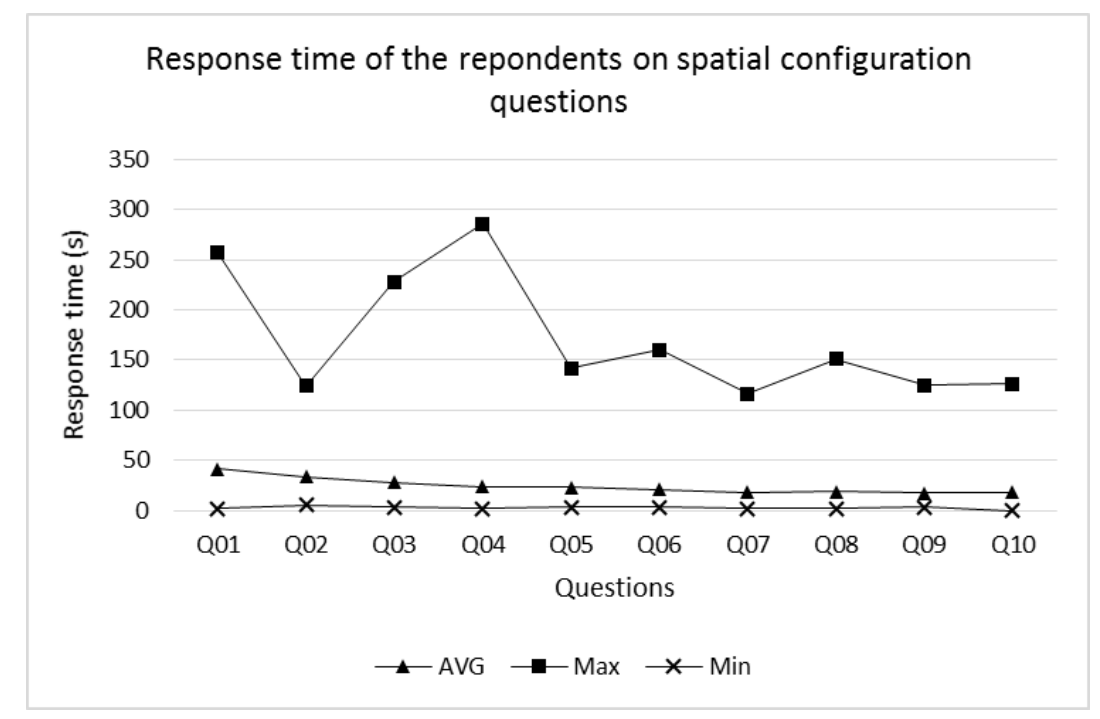

Figure 8. The response time of the respondents on spatial configuration questions (analysis, 2016)

There are several reasons which might explain the result of the survey. First, the resolution of the satellite imagery which is use in the question is not high. Consequently, respondents could have difficulties in differentiating between buildings and other features such as road, shrimp ponds, or difficulties in differentiating the road intersections due to the limited sharpness of the satellite imagery. The second possibility is that the questions in this aspect could be too difficult to grasp by the respondents, either due to the nature of the questions which only present images and symbols with the minimum description, or due to the unfamiliarity of the respondent to the map and satellite imagery.

Regardless, this finding suggests that there is a difficulty among the respondents in creating a connection between a map or satellite imagery and the corresponding environment. This difficulty could create a problem since map or satellite imagery is used extensively by the government in the dissemination of disaster management planning information to the general public. The use of map or satellite imagery as a tool for communicating the disaster management planning information should present in a way that is easy to read and understand by the general public. Besides that, the use of these tools should accompany by the increasing level of people's understanding of the tools itself, especially if the tools are used for the local villagers.

The field survey result on the different aspect also indicates the low level of people's understanding on disaster mitigation (Figure 9). Based on the field survey results, around 65 percent of the respondents seems to have limited understanding regarding the tsunami mitigation planning at the local government level, especially the information related to the location of the tsunami evacuation building/shelter, even though the general information regarding this aspect is already adopted in the local development planning document, while the more detailed information is already adopted in the draft of local contingency planning documents. The other 35 percent of the respondents answered the question but give various answers. This finding could suggest either the lack of people's curiosity towards the local disaster 
management planning information or the lack of local government efforts in disseminating the issue of disaster preparedness to the smallest unit in the community.
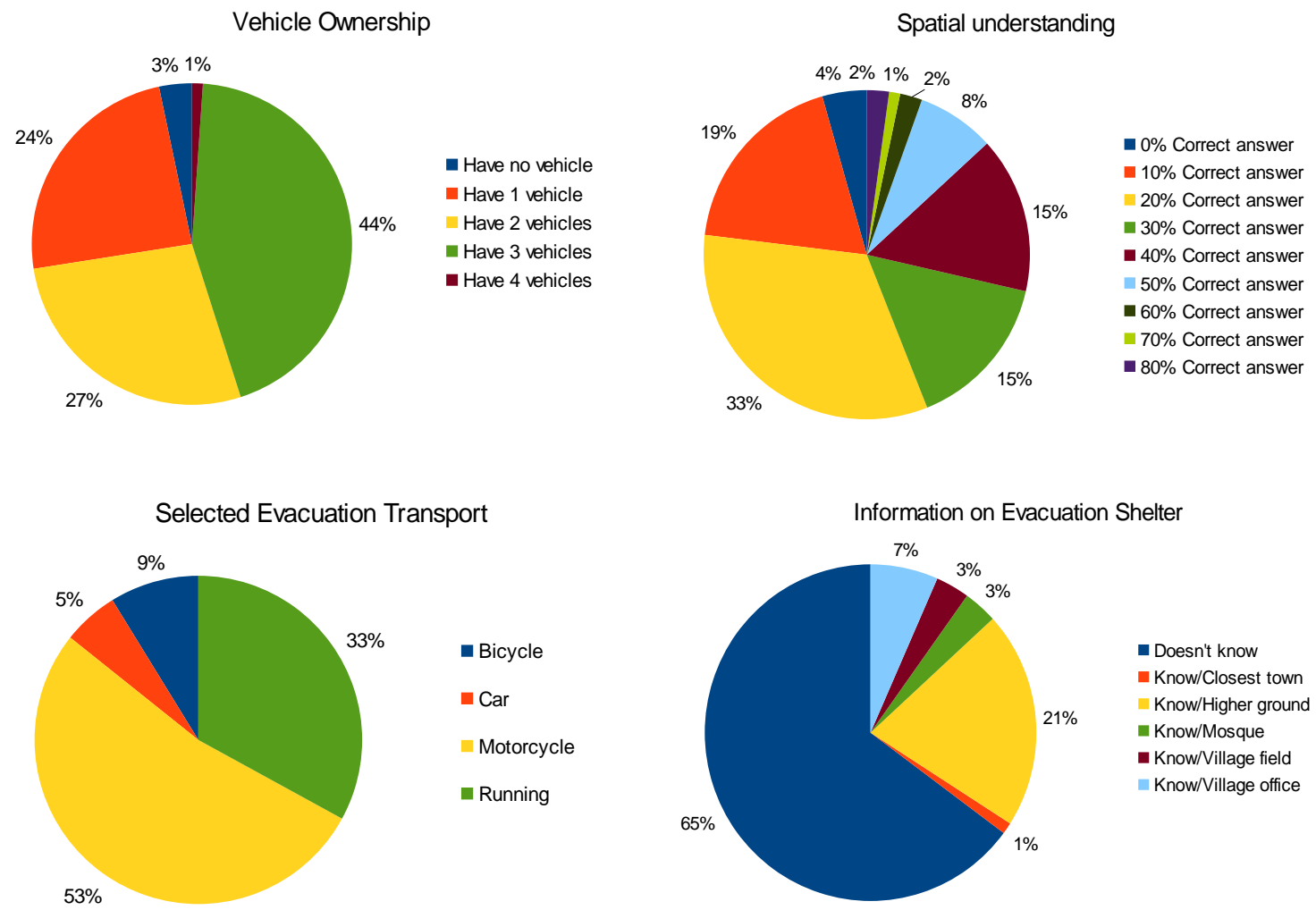

Figure 9. Result of survey regarding spatial configuration understanding and tsunami evacuation aspect (analysis, 2016)

In the context of disaster management planning, the result implies a need for a new method of communicating the disaster-related information to the villagers. Less formal dissemination materials such as comic, graphic booklet, photo book, or audio book (i.e. for people with disability), instead of a map full of symbols could be easier to read and comprehend by the local villagers. Other than that, the dissemination of disaster management planning information on a regular basis is essential to build public awareness on disaster mitigation continuously. Integrating the disaster management knowledge as a part of the course at the school could also be an option.

\section{CONCLUSION}

Current methods of tsunami-related disaster evacuation preparation predominantly focus on infrastructure and urban centers. In order to include more rural areas and smaller cities, alternative methods are needed. The selected GIS-based tsunami evacuation model in this research relies on a Least Cost Path method, which is a raster-based model. The model is selected for its flexibility, especially when used to represent tsunami evacuation for different land cover classes and spatial configuration. The rasterbased approach is considered more appropriate for modeling tsunami evacuation processes in a less to the medium developed urban area such as the study area. It is in any case better than the vector-based approach, which is developed for highly developed urban areas.

The land cover aspect and spatial configuration aspect is shown to have influence on the tsunami evacuation process. Land cover aspect influences especially the accessibility of each PTEB in terms of evacuation time whilst the spatial configuration aspect influences the visibility profile along the PTER. Even though the general visibility of the tsunami evacuation route is good, there is a possibility of a two dimensional visibility drop in certain junctions or nodes. The test results also show that there is a disproportionate distribution of the tsunami evacuation capacity in the study area, which needs to be 
redressed. Some PTEBs need to be improved in order to cater for the number of the potential evacuees within its service area.

Given these results, there are several recommendations both for the local government side, the disaster manager working closely with the people, and the community which is living in the tsunami-prone coastal areas. The recommendations include (1) the adapted GIS-based tsunami evacuation model could be used by the local disaster managers to enrich the information regarding the tsunami threat in the Purworejo Regency in a spatial planning document. It is valuable material for a capacity assessment, both for local government officers, disaster managers, and the community. (2) Local governments which include tsunami mitigation as a priority in their development planning document have the opportunity to replicate the GISbased tsunami evacuation model applied in this work, by following the workflow provided in this study. (3) The government could improve the existing public facility buildings which are targeted to be used as a vertical tsunami evacuation building in tsunami-prone coastal areas to anticipate future tsunami threats. (4) Disaster managers could use the new approach to disseminate information about tsunami hazard risks. This is possible for example by using more graphic materials such as comic books, graphic booklets, photo books, or audio books (i.e. for people with disability), instead of relying on a map full of symbols. This variety could be easier to read and comprehended by the local villagers. (5) There is an urgent need to involve the community in disaster mitigation efforts, in order to build community awareness about disaster risks.

\section{ACKNOWLEDGMENTS}

I would like to express my gratitude especially to the Ministry of Public Works and Housing of the Republic of Indonesia, for the scholarships and funding support for this research.

\section{REFERENCES}

Agency for Meteorology Climatology and Geophysic. (2010). InaTEWS: Indonesia Tsunami Early Warning System Concept and Implementation. Jakarta.

Babeyko, A. (2012). EasyWave: fast tsunami simulation tool for early warning.

Budiarjo, A. (2006). Evacuation Shelter Building Planning for Tsunami-prone Area; a Case Study of Meulaboh City, Indonesia. ITC Enschede.

Dewi, R. S. (2010). A GIS-Based Approach to the Selection of Evacuation Shelter Building and Routes for Tsunami Risk Reduction- A Case Study of Cilacap Coastal Area, Indonesia. University of Twente.

Dijkstra, E. W. (1959). A note on two problems in connexion with graphs. Numerische Mathematik, 1(1), 269-271. [Crossref]

Fakhrurrazi, \& Nes, A. van. (2012). Space and Panic. The application of Space Syntax to understand the relationship between mortality rates and spatial configuration in Banda Aceh during the tsunami 2004. In M. Greene, J. Reyes, \& A. Castro (Eds.), Eighth International Space Syntax Symposium. Santiago de Chile.

FEMA. (2008). Guidelines for Design of Structures for Vertical Evacuation from Tsunamis. [Crossref]

Gayer, G., et. al. (2010). Tsunami inundation modelling based on detailed roughness maps of densely populated areas. Natural Hazards and Earth System Sciences, 10, 1679- 1687. [Crossref]

Grimmond, C. S. B., et al. (2001). Rapid methods to estimate sky-view factors appiled to urban areas. International Journal of Climatology, 21, 903-913. [Crossref]

Hakim, F. F. (2016). Application of GIS-based Tsunami Evacuation Model Considering Land Cover and Spatial Configuration Case of Purworejo Regency, Indonesia. Technische Universität München.

Juliao, R. P. (1999). Measuring accessibility using GIS.

Kaiser, G., et al. (2013). Mapping tsunami impacts on land cover and related ecosystem service supply in Phang Nga, Thailand, 3095-3111. [Crossref]

Kaiser, G., et. al. (2011). The influence of land cover roughness on the results of high resolution tsunami inundation modeling. Natural Hazards and Earth System Sciences, 11, 2521-2540. [Crossref]

Kongko, W. \& Hidayat, R. (2014). Earthquake-Tsunami in South Jogjakarta Indonesia: Potential, Simulation Models, and Related Mitigation Efforts. IOSR Journal of Applied Geology and Geophysics, 2(3), 18-22. 
Lonergan, C. D. (2011). Advancing Tsunami Risk Communication through Geographic Vizualization. Simon Fraser University.

Menke, K., et. al. (2015). Mastering QGIS. Mumbai: PACKT Publishing.

Mück, M. (2008). Tsunami Evacuation Modelling: Development and application of a spatial information system supporting tsunami evacuation planning in South-West Bali. Universität Regensburg.

Münch, U., Rudloff, A., \& Lauterjung, J. (2011). Postface "The GITEWS Project - results, summary and outlook". Natural Hazards and Earth System Sciences, 11, 765-769. [Crossref]

Pemerintah Kabupaten Purworejo. (2011). Rencana Tata Ruang Wilayah Kabupaten Purworejo 2011-2031. Purworejo.

Roberts, S., et. al. (2015). ANUGA User Manual Release 2.0. Geoscience Australia.

Romer, H., et. al. (2012). Potential of remote sensing techniques for tsunami hazard and vulnerability analysis - a case study from Phang-Nga province, Thailand. Natural Hazards and Earth System Sciences, 12, 2103-2126. [Crossref]

Samek, J. H., Skole, D. L., \& Chomentowski, W. (2004). Assessment of Impact of the December 262004 Tsunami In Aceh Province Indonesia.

Schiff, J. L. (2011). Two-Dimensional Automata. In Cellular Automata: A Discrete View of the World (p. 272). John Wiley \& Sons.

Schmidtlein, M. C., \& Wood, N. J. (2015). Sensitivity of tsunami evacuation modeling to direction and land cover assumptions. Applied Geography, 56, 154-163. [Crossref]

Soule, R. G., \& Goldman, R. F. (1972). Terrain coefficients for energy cost prediction. Journal of Applied Physiology, 32(5), 706-708.

Sturnz, G., et. al. (2011). Tsunami risk assessment in Indonesia. Natural Hazards and Earth System Sciences, 11, 67-82. [Crossref]

USGS. (2004). Filling the Gaps to use in Scientific Analysis.

USGS. (2015). US Land Cover.

Wood, N. (2009). Tsunami exposure estimation with land-cover data: Oregon and the Cascadia subduction zone. Applied Geography, 29(2), 158-170. [Crossref]

Wood, N. J., \& Schmidtlein, M. C. (2012). Anisotropic path modeling to assess pedestrian-evacuation potential from Cascadia-related tsunamis in the US Pacific Northwest. Natural Hazards, 62(2), 275300. [Crossref] 